\title{
THE EFFECT OF TRANSIENT AND PERSISTENT NEONATAL HYPOTHYROIDISM ON THE ADULT ALBINO RAT TESTIS (LIGHT AND ELECTRON MICROSCOPE STUDIES
}

\author{
Laila M. Elshall \\ Histology Department, Faculty of Medicine, Zagazig University
}

\begin{abstract}
Introduction and aim of work: thyroid hormone is known to play a critical role in the development and growth of the testis. So, this study was designed to compare between the effect of transient and persistent neonatal hypothyroidism on the testis of adult rats. Material and Methods: Thirty newborn rats ( 1 day old) were classified equally into control group and two experimental groups. In experimental group I, the transient hypothyroidism was induced in neonates by giving their lactating mothers $0.05 \%$, 6-propyl-2 thiouracil (PTU) through drinking water for 30 days after birth then the treatment was withdrawal for 60 days. In experimental group II, the persistent hypothyroidism was induced by giving the neonates $0.05 \%$ PTU through their mother milk until weaning then directly through drinking water for 90 days after birth. After 90 days postpartum, all animals were anaesthetized and their testes were dissected out and processed for light and electron microscope examination. Results: In experimental group I, the testes of transient hypothyroid rats appeared with large seminiferous tubules (ST) that the length of their diameters and the height of their lining epithelium were significantly increased as compared to those of control rats. They were lined by many Sertoli cells, primary spermatocytes, secondary spermatocytes, early spermatides and late spermatids. The interstitial spaces contained some Leydig cells and few fluid. In experimental group II, the testes of persistent hypothyroid rats appeared with small ST that the length of their diameters and the height of their lining epithelium were significantly decreased as compared to those of control rats. They were lined by thin disorganized germinal epithelium containing many Sertoli cells and few germ cells. Many sloughed degenerating cells and large multinucleated giant cells were seen in the lumen of ST. The interstitial spaces contained many connective tissue cells, congested blood vessels, excessive collagen fibers and abundant fluid. Electron microscope examination, revealed Sertoli cells which were surrounded by wide spaces due to loss of germ cells. They contained distorted mitochondria, nuclei with peripheral heterochromatin condensation and free processes due to loss of tight junction between them. In conclusion, the present study revealed that the neonatal transient hypothyroidism enhanced the growth of the testes that they contained large seminiferous tubules with many germ cells. While, the persistent hypothyroidism induced testicular atrophy with degeneration of germ cells. So, estimation of thyroid hormone level is recommended in all neonates immediately after birth for early diagnosis and treatment of thyroid hormone deficiency to prevent serious adverse effect of hypothyroidism on the testis.
\end{abstract}

\section{INTRODUCTION}

The thyroid gland develops from the floor of the primitive pharynx and begins to synthesize and secrete $\mathrm{T}_{4}$ by 17 days of gestation (Morreale de Escobaret et al.,1985).

The most numerous cell population in the gland is the thyroid follicular cells which are responsible for secretion of iodedtyrosine derived hormones. They exert important effects on development, growth and metabolism of differentorgans(Ten,2001andBernal,2005).
Some of their most prominent effects occur during fetal development and early childhood while several organs undergo significant morphological and physiological changes (Choksi et al.,2003).

The testis has been classically described as a thyroid hormone unresponsive tissue, first, it has been thought that delayed gonadal maturation observed in hypothyroid animals and man has been attributed to a reduction of 
gonadotrophin secretion(Jannini et al.,1995). Modified hypothalamo-hypophyseal testiculart axis in hypothyroid rodents and human has been well documented. Hypothyroidism induces changes in gonotrophins and

gonadotrophin releasing hormone in association with changes in testosterone and estradiol (Maran et al.,2001).Recent studies indicated that thyroid hormone might play a direct important role in developing testes by affecting on $\mathrm{T}_{3}$ receptors which are identified in Sertoli cells(Rao et al.,2003).

The physiological importance of thyroid hormones becomes most evident under the conditions of congenital hypothyroidism, cretinism, which is a syndrome characterized by metabolic disturbance, neurological defects, mental retardation and infertility(De Felice and Di Iauro, 2004).In several studies, a hypothyroid state was induced by thyroidectomy(Biswas et al.,1994)or by administration of antithyroid drugs(Loveland et al.,1998). Propylthiouracil (PTU) is a thioamide drug used clinically to inhibit thyroid hormone production by multiple mechanisms. It inhibits oxidation of iodide to oxidized iodine and it's binding to tyrosine moieties in thyroglobulin. Also, it suppresses the conversion of peripheral $\mathrm{T}_{4}$ to $\mathrm{T}_{3}$ so reduces serum $\mathrm{T}_{3}$ concentration(Chioo et al.,2002). It is commonly used to treat hyperthyroidism conditions such as Graves disease. This drug is known to be able to cross the placenta(Morchart et al.,1977) and to be secreted in milk of lactating mothers(Momotani et al.,2000)It has been linked with several side effects such as transient leucopenia, jaundice, hepatomegaly (Deidiker and Mello,1996)and vascularities (Chastain $e t$ al.,1999).

The nature of intensity of hypothyroidism effect will undergo variation depending upon age and species of the animals, duration and mode of hypothyroidism induction(Maran et al.,1999). In most mammals, the fetal, neonatal and prepubertal periods have important physiological significance in the testis (Sharpe et al.,2003).So, the present study was designed to compare between the effect of neonatal transient and persistent experimentally induced hypothyroidism on the histological structure of adult male albino rat testis.

\section{MATERIAL AND METHODS}

Thirty newborn male rats (one day old) were obtained from the breeding animal's house of IFaculty of Veterinary Medicine, Zagazig University. They were maintained under controlled conditions of temperature $\left(20-25^{\circ} \mathrm{C}\right)$ and lighting (12 hours light, 12 hours dark). They were classified into three equal groups (10 animals each) one control group and two experimental groups. In experimental group I, the transient hypothyroidism was induced in neonates by giving their lactating mothers 0.05\% 6-propyl-2-thiouracil (PTU) (Sigma Chemical Co.) through drinking water for 30 days after birth and then the animals were left untreated for 60 days(Sahoo et al.,2008).In experimental group II (persistent hypothyroidism), the neonates received $0.05 \%$ PTU through mother's milk until weaning then directly through drinking water containing $0.05 \%$ PTU for 90 days after $\operatorname{birth}($ Sahoo et al.,2008).After 90 days postpartum, all animals were anaesthetized with ether inhalation and their testes were dissected out and processed for light and electron microscope examinations. Specimens for light microscope examination were fixed in $10 \%$ neutral formol saline. They were processed to prepare $5 \mu \mathrm{m}$ thick paraffin sections. For haematoxylin and Eosin $(\mathrm{H} \& \mathrm{E})$ and Mallory's trichrome stain(Bancroft and Gamble,2002).Specimens for electron microscope examination were immediately fixed in $2.5 \%$ glutaraldehyde buffered with 0.1 $\mathrm{M}$ phosphate buffer at $\mathrm{pH} 7.4$ for 2 hours at $4^{\circ} \mathrm{C}$ and then post fixed in $1 \%$ osmium tetroxide in the same buffer for one hour at $4^{\circ} \mathrm{C}$. Specimens were dehydrated with ascending grades of ethanol and were put in propylene oxide for 30 minutes at room temperature. They were impregnated in a mixture of propylene oxide and resin (1:1) for 1 hour then in a mixture of the previous reagents at $48^{\circ} \mathrm{C}$ for 1 hour. The specimens were embedded in Embed-812 resin in BEEM capsules at $60^{\circ} \mathrm{C}$ for 24 hours. Ultra thin sections were obtained using leica ultra cut UCT and stained with uranyl acetate and lead citrate(Glauert and Lewis,1998) and examined with JEOL JEM 1010 electron microscope in the Electron Microscope Research Laboratory (EMRL) of Histology Department, Faculty of 
Medicine, Zagazig University.

\section{Quantitative morphometric measurements:}

The diameter of seminiferous tubules and the height of epithelium lining them were measured by using "leica Quin 500" image analyzer computer system (leica imaging system LtD, Cambridge, England). Measurements were done within 10 non-overlapping fields for each animal at X400 magnification for measurement the diameter of seminiferous tubules and at X100 magnification for measuring the height of their lining epithelium. The quantitative morphometric measurement were done in Histology Department, Faculty of Medicine, Cairo University.

Statistical analysis:

The data obtained from the image analyzer were analyzed on an IBM PC, using the statistical software "Statistical for Window". The parameters were tested using student " $\mathrm{T}$ " test and the results were considered significant when $\mathrm{P}>0.05^{(21)}$.

\section{RESULTS}

Light microscope examination of sections in the testes of adult male rats (90 days old) revealed that the testicular parenchyma was formed of many seminiferous tubules. They were lined by stratified germinal epithelium and separated by interstitial spaces containing few Leydig cells (Fig. 1). The seminiferous tubules were lined by spermatogonia with small dark nuclei and Sertoli cells with large pale nuclei. Both cells were found close to the basement membranes. Primary spermatocytes with large rounded nuclei, early spermatids with rounded pale nuclei and late elongated darkly stained spermatids were also seen. Each seminiferous tubule was surrounded by their limiting basement membrane with myoid cells (Fig. 2). Few collagen fibers were seen around the seminiferous tubules and in the interstitial spaces (Fig. 3).

Electron microscope examination of sections in adult control male rats revealed spermatogonia containing nuclei with peripheral clumps of heterochromatin, free ribosomes and mitochondria (Fig. 4). Primary spermatocytes appeared with large rounded nuclei containing scattered clumps of heterochromatin and mitochondria (Fig. 5).

Sertoli cells were seen close to the basement membrane. They had lateral long processes which joined with that of adjacent Sertoli cells by tight junction (blood testis barrier). They contain large indended nuclei with dispersed chromatin and mitochondria (Fig. 5). Early spermatids contained rounded nuclei with dispersed chromatin and peripheral mitochondria with electron dense membranes. Late spermatides were seen with electron dense nuclei and tails (Fig. 6).Light microscope examination of sections in testis of trannsient hypothyroid rats showed seminiferous tubules with long diameters and narrow lumen. They are lined by many layers of germinal epithelium. The interstitial spaces contained some cells embedded in few acidophilic interstitial fluid (Fig. 7). Each seminiferous tubule was lined by separmatogonia many sertoli cells, primary spermatocytes, many layers of early spermatids and late spermatids (Fig. 8). Few collagen fibers were seen around the seminiferous tubules and in the interstitial spaces (Fig. 9).

Electron microscope examination of the sections in the testes of transient hypothyroid rats showed spermatogonia which contained nuclei with clumps of heterochromatin and mitochondria. Sertoli cells appeared with lateral process join with each other around the spermatogonia (Fig. 10). The Sertoli cells contained indented nuclei with dispersed chromatin, prominent nucleoli and mitochondria (Figs. 10, 11). Basement membrane is surrounded by two layers of myoid cells (Fig. 11). Primary spermatocytes appeared with nuclei containing scattered clumps of heterochromatin and mitochondria (Fig. 12). Many layers of early spermatids were seen. They had rounded nuclei with dispersed chromatin and peripheral mitochondria with electron dense membrane (Figs. 13, 14). Mid pieces of the sperms with mitochondrial sheaths and central microtubules were observed (Fig. 14).

Light microscope examination of the sections in the testis of persistent hypothyroid rats showed small seminiferous tubules lined by thin disorganized germinal epithelium. They were separated by wide interstitial spaces containing abundant interstitial fluid, vacuoles, many Sertoli cells and congested blood vessels (Fig. 15). Some seminiferous tubules were lined by many Sertoli cells with oval pale nuclei and cytoplasmic processes which fused together forming large vacuoles between the germ cells 
(Fig. 16).Some primary spermatocytes appeared at different stages of cell division with few distorted late spermatids between them (Fig. 17). Some tubules showed loss of most of the lining cells except few spermatocytes and Sertoli cells (Fig. 18). Sloughed degenerating germ cells with small pyknotic nuclei and pale cytoplasm and large multinucleated giant cells were seen in the lumen of the seminiferous tubules (Fig. 19). Also, other seminiferous tubules were only lined by many Sertoli cells forming single layer close to the basement membrane (Fig. 20). Many collagen fibers and congested blood vessels were seen in the interstitial spaces between the seminiferous tubules (Fig. 21).

Electron microscope examination of the sections in the testis of persistent hypothyroid rats revealed Sertoli cells with distorted mitochondria and disorganized tight junctions between adjacent cells (Fig. 22). Some Sertoli cells contained nuclei with peripheral heterochromatin condensation, distorted tight junctions and large vacuoles between their processes (Fig. 23). While, other Sertoli cells appeared widely separated with free processes. The interstitial spaces contained many collagen fibers and fibroblasts (Fig. 24).

\section{The morphometric results:}

The present study revealed that the diameter of seminiferous tubules of the testes significantly increased in transient hypothyroid rats as compared to those of control rats and significantly decreased in persistent hypothyroid rats as compared to those of control rats (Table 1).

Also, the height of epithelium lining the seminiferous tubules of the testes significantly increased in transient hypothyroid rats as compared to those of control rats and significantly decreased in persistent hypothyroid rats as compared to those of control rats (Table 2). 


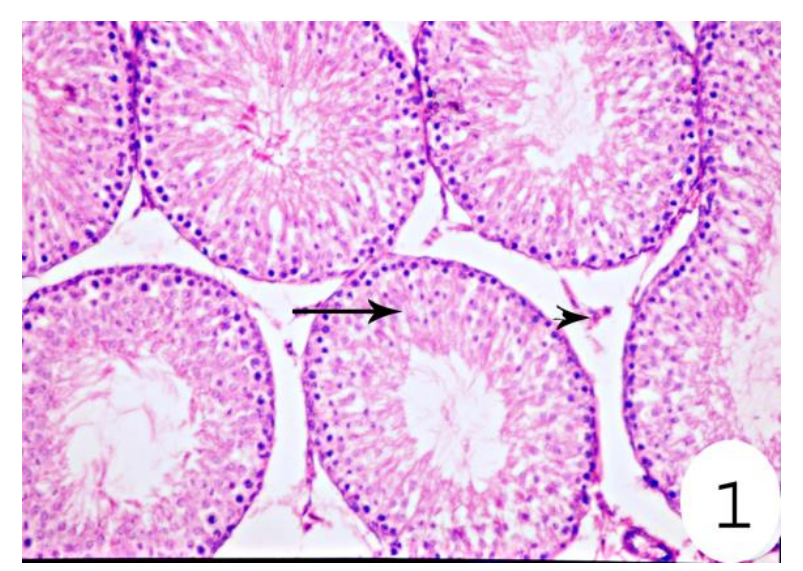

Fig. (1): A photomicrograph of a section in the testis of a control rat (90 days old) showing many seminiferous tubules lined by stratified germinal epithelium (arrow) and separated by interstitial spaces containing few Leydig cells (arrow head). X 200)

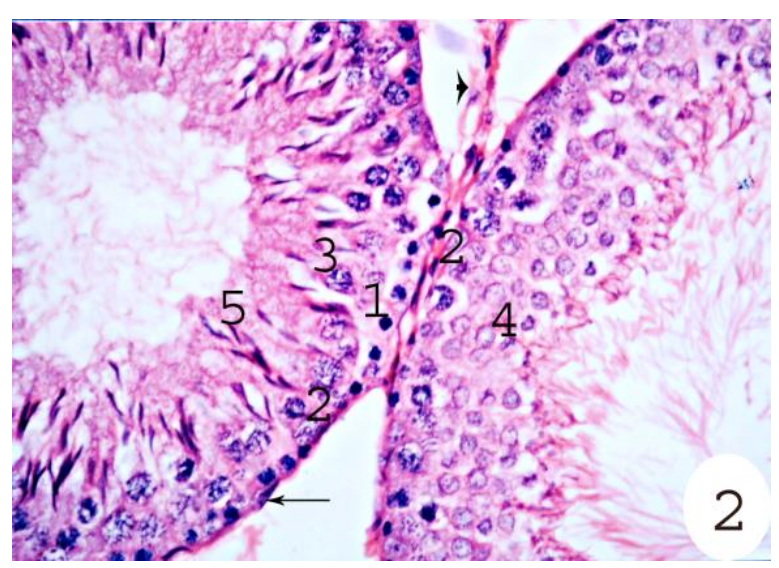

Fig. (2): A photomicrograph of a section in the testis of a control rat (90 days old) showing seminiferous tubules lined by spermatogonia (1) and Sertoli cells (2) close to the basement membrane. Primary spermatocytes (3), early (round) spermatids (4) and late (elongated) spermatids (5) are also seen. Myoid cells with flat nuclei (arrow) and interstitial spaces containing few Leydig cells (arrow head) are noticed. (H \& E X 400)

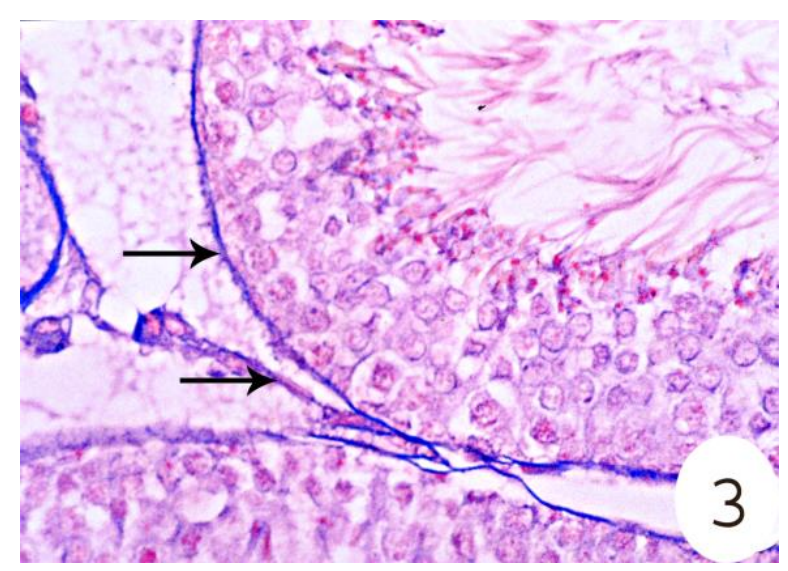

Fig. (3): A photomicrograph of a section in the testis of a control rat (90 days old) showing few collagen fibers (arrow) around the seminiferous tubules and in the interstitial spaces. (Mallory's trichrome stain X 400) 

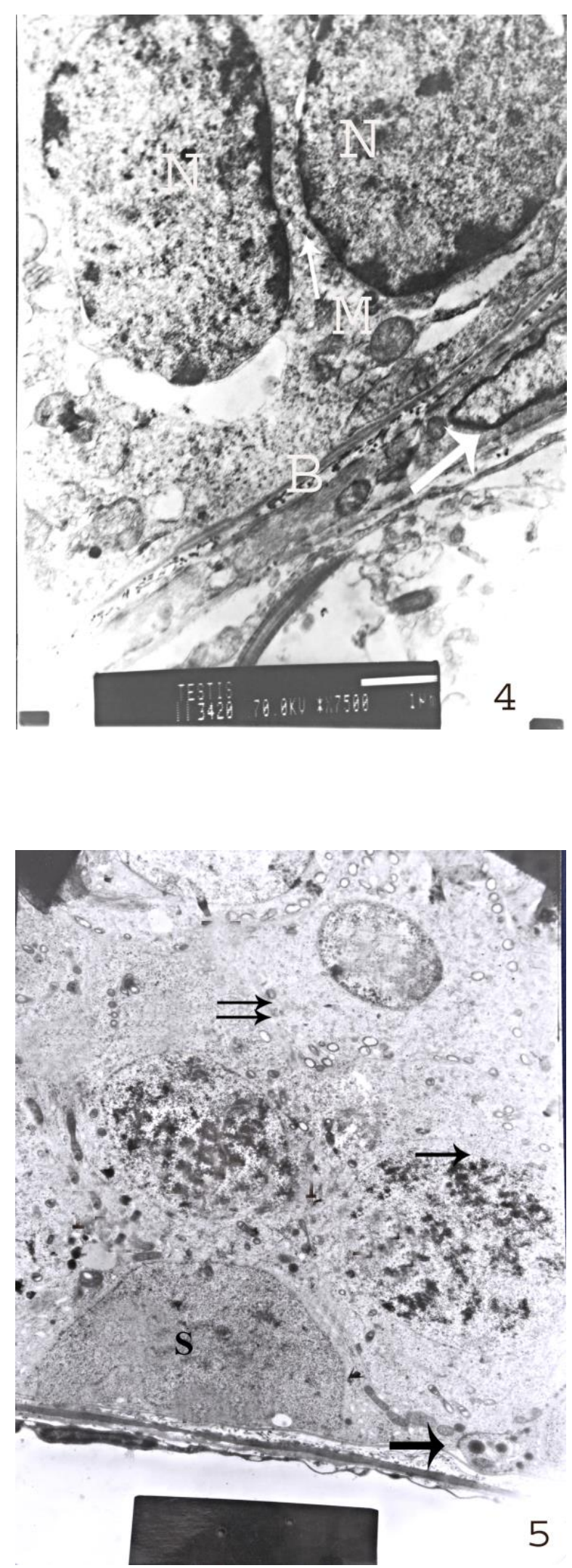

Fig. (4): A transmission electron micrograph of a section in the testis of a control rat $(90$ days old) showing two spermatogonia containing nuclei $(\mathrm{N})$ with peripheral clumps of heterochromatin free ribosome (thin arrow) and mitochondria (M). Basement membrane (B) and myoid cells (thick arrow) are seen.

(X 17000)
Fig. (5): A transmission electron micrograph of a section in the testis of a control rat $(90$ days old) showing Sertoli cell (S) close to the basement membrane. It contains indented nucleus, mitochondria and long processes joined with adjacent Sertoli cell by tight junction (thick arrow) (blood testis barrier). Primary spermatocytes appear with (thin arrow) mitochondria and rounded nuclei containing scattered clumps of heterochromatin. Early spermatids (double arrow) with ovoid nucleus and peripheral mitochondria with electron dense membrane are seen.

(X 3000) 


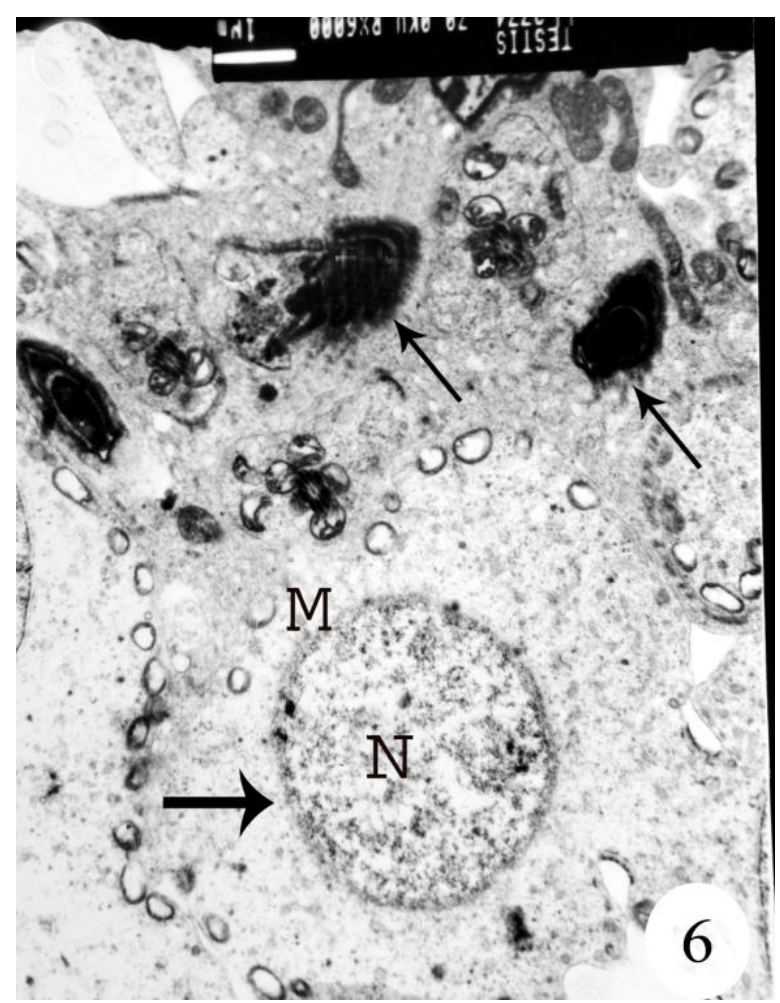

Fig. (6): A transmission electron micrograph of a section in the testis of control rat (90 days old) early spermatids (thick arrow) containing rounded nuclei $(\mathrm{N})$ with dispersed chromatin and peripheral mitochondria $(\mathrm{M})$ with electron dense membranes. Late spermatids (thin arrow) with electron dense nuclei and tail are noticed.

(X 12000)

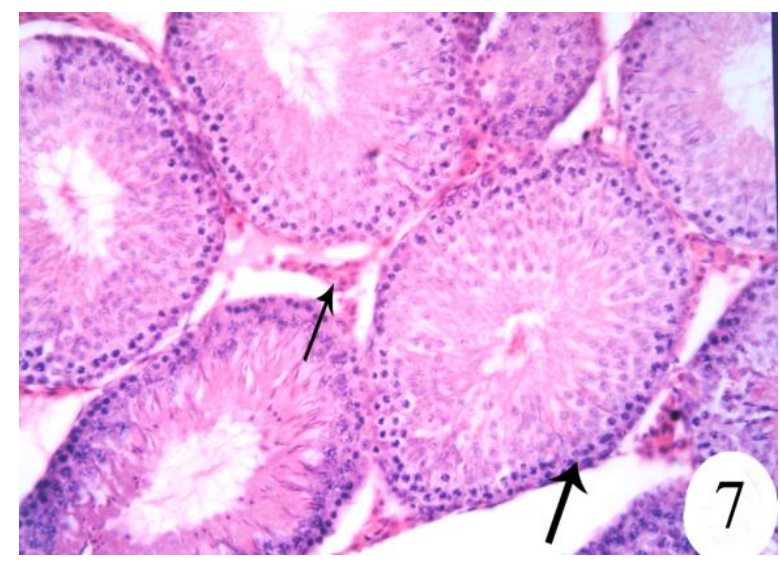

Fig. (7): A photomicrograph of a section in the testis of transient hypothyroid (90 days old) treated with PTU for 30 days after birth showing seminiferous tubules with large diameters and narrow lumen (thick arrow). They are lined by many layers of germinal epithelium. The interstitial spaces contain some interstitial cells (thin arrow) and little acidophilic fluid. (H \& E X 200)

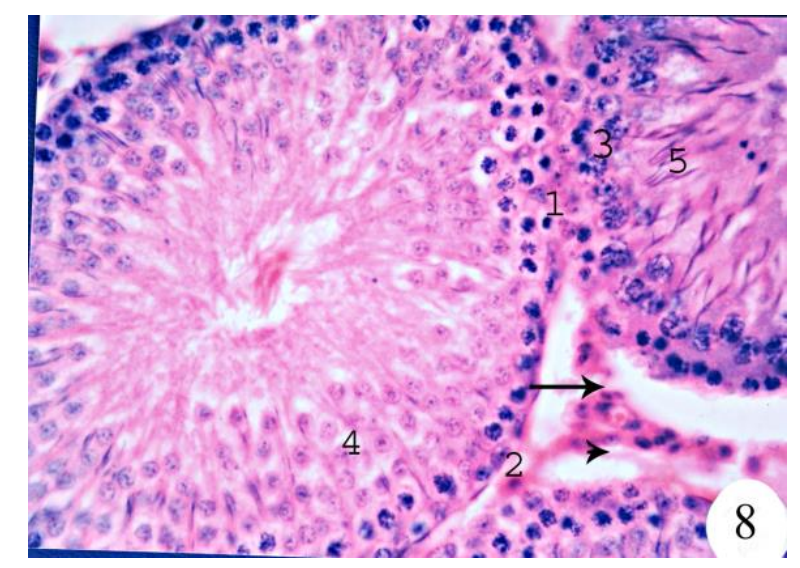

Fig. (8): A higher magnification of figure (8) showing large seminiferous tubules lined by many layer of germinal epithelium containing spermatogonia (1), many Sertoli cells (2), primary spermatocytes (3), many layers of early spermatids (4) and late spermatids (5). Interstitial spaces contain some interstitial cells (thin arrow) embedded in few acidophilic fluid (arrow head).

(H \& E X 400) 


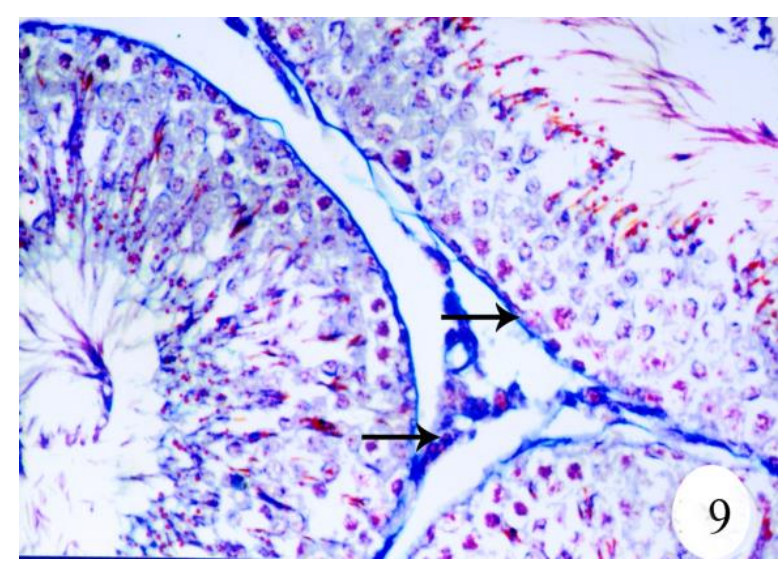

Fig. (9): A photomicrograph of a section in the testis of an adult transient hypothyroid rat (90 days old) treated with PTU for 30 days after birth showing few collagen fibers (arrow) around the seminiferous tubules and in the interstitial spaces.

(Mallory's trichrome stain X 400)

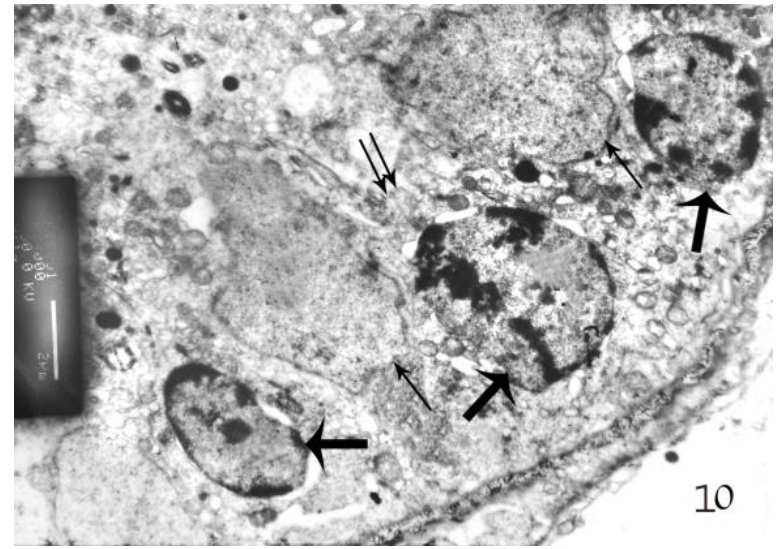

Fig. (10): A transmission electron micrograph of a section in the testis of transient hypothyroid adult rats (90 days old) treated with PTU for 30 days after birth showing spermatogonia and Sertoli cells resting on the basement membrane. Spermatogonia appear with nuclei (thick arrow) containing clumps of heterochromatin and mitochondria. Sertoli cells (thin arrow) appear with indented nuclei containing dispersed chromatin and lateral processes. Join with each other around the spermatogonia (double arrow). (X 9000)

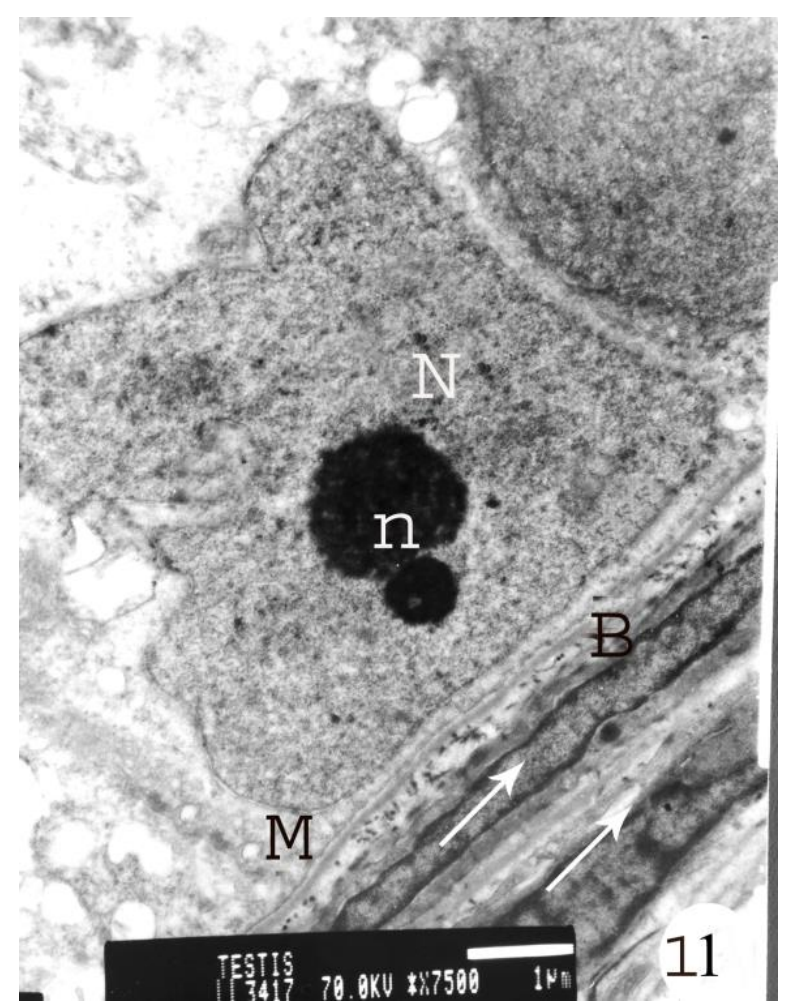

Fig. (11): A transmission electron micrograph of a section in the testis of transient hypothyroid adult rats (90 days old) treated with PTU for 30 days after birth showing Sertoli cells with indented nuclei (N) containing dispersed chromatin , prominent nucleoli (n). Basement membrane (B) is surrounded by two layers of myoid cells (thin arrow).

(X 17000) 

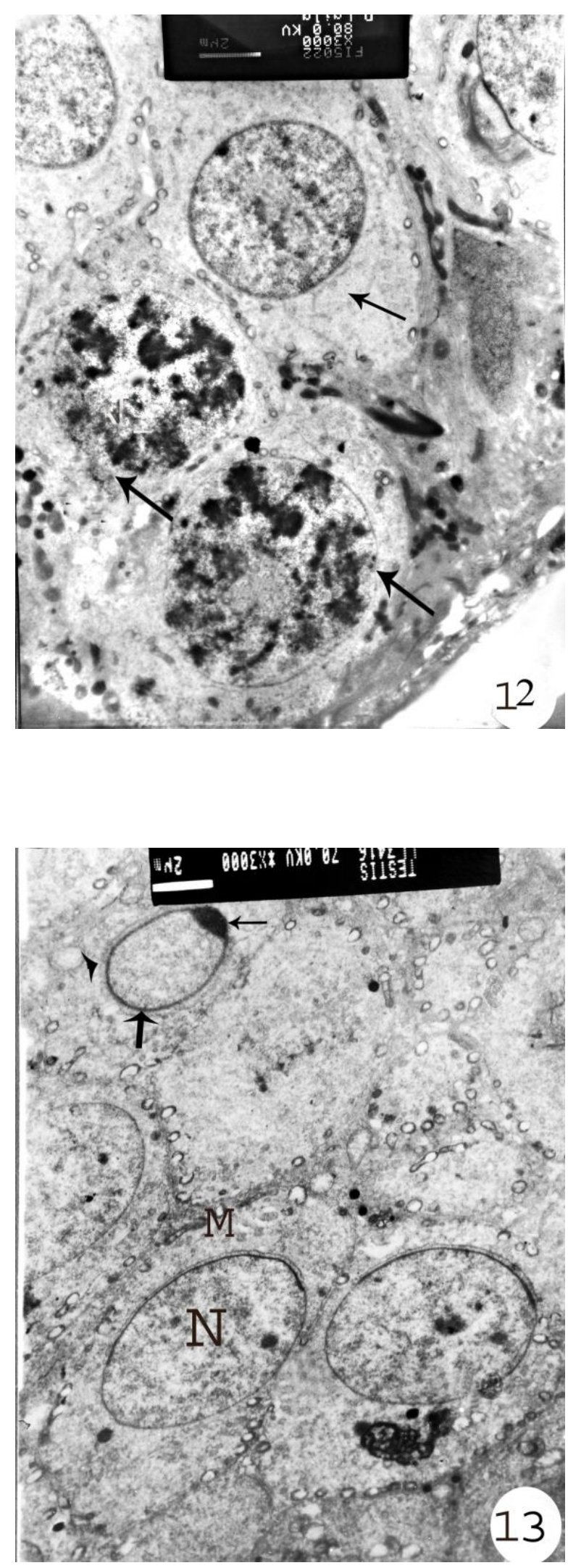

Fig. (12): A transmission electron micrograph of a section in the testis of a transient hypothyroid adult rats (90 days old) treated with PTU for 30 days after birth showing primary spermatocytes (thick arrow) with nuclei containing scattered clumps of heterochromatin and mitochondria. Early spermatids (thin arrow) contain nuclei with dispersed chromatin and peripheral mitochondria with electron dense membrane.

(X 17000)

Fig. (13): A transmission electron micrograph of a section in the testis of a transient hypothyroid adult rat (90 days old) treated with PTU for 30 days after birth showing many layers of early spermatids. Each of them has nucleus $(\mathrm{N})$ with dispersed chromatin and peripheral mitochondria (M) with electron dense membrane. One spermatid (thick arrow) appears with acrosomal cap (thin arrow) and electron dense nuclear envelope (arrow head).

(X 6000) 

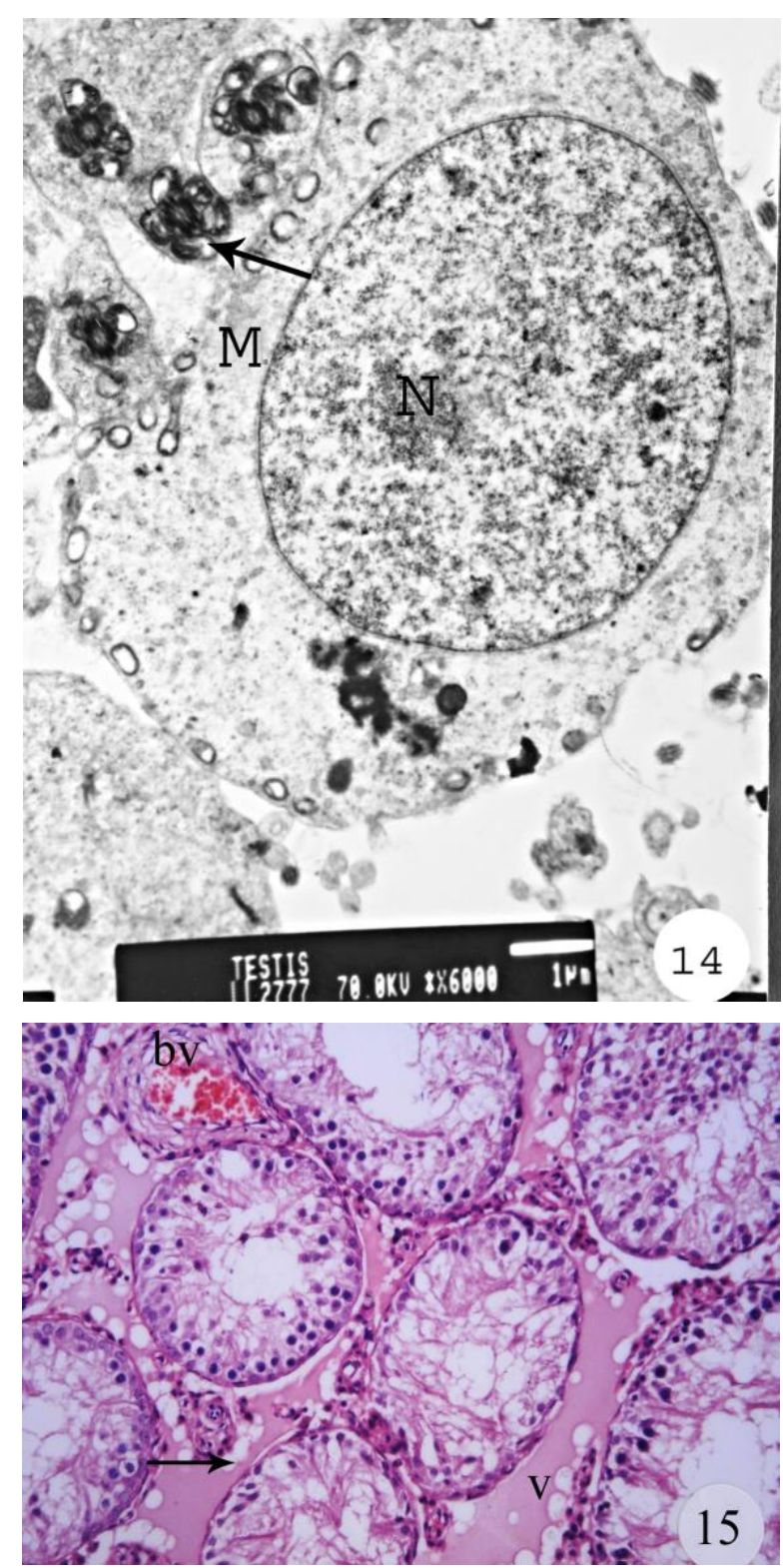

Fig. (15): A photomicrograph of a section in the testis of persistent hypothyroid adult rats (90 days old) treated with PTU for 90 days after birth showing small seminiferous tubules. They are lined by few layers of disorganized germinal epithelium. Wide interstitial spaces contain abundant interstitial acidophilic fluid, many cellular (arrow) vacuoles (V) and congested blood vessels (BV).

(H \& E X 200)
Fig. (14): A transmission electron micrograph of a section in the testis of a transient hypothyroid adult rats (90 days old) treated with PTU for 30 days after birth showing early spermatid with nucleus (N) containing dispersed chromatin and peripheral mitochondria with electron dense membrane (M). Mid pieces of the sperms with mitochondrial sheaths (arrow) and central microtubules are observed. (12000)

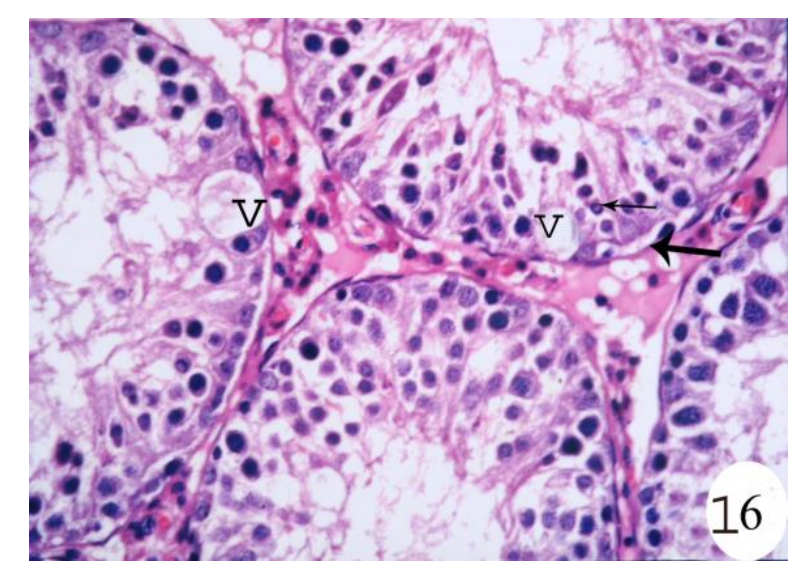

Fig. (16): A photomicrograph of a section in the testis of persistent hypothyroid adult rats (90 days old) treated with PTU for 90 days after birth showing seminiferous tubules line by widely separated disorganized germinal epithelium. Many Sertoli cells are seen (thick arrow) close to the basement membrane. They have oval pale nuclei and long cytoplasmic processes. Some processes of Sertoli cells fused together forming vacuoles (V) between the germinal epithelium. Primary spermatocytes (thin arrow) appear with dark nuclei and pale cytoplasm. Interstitial spaces contain many Leydig cells, and abundant interstitial fluid. $\quad(\mathrm{H} \& \mathrm{E}$ X 400) 


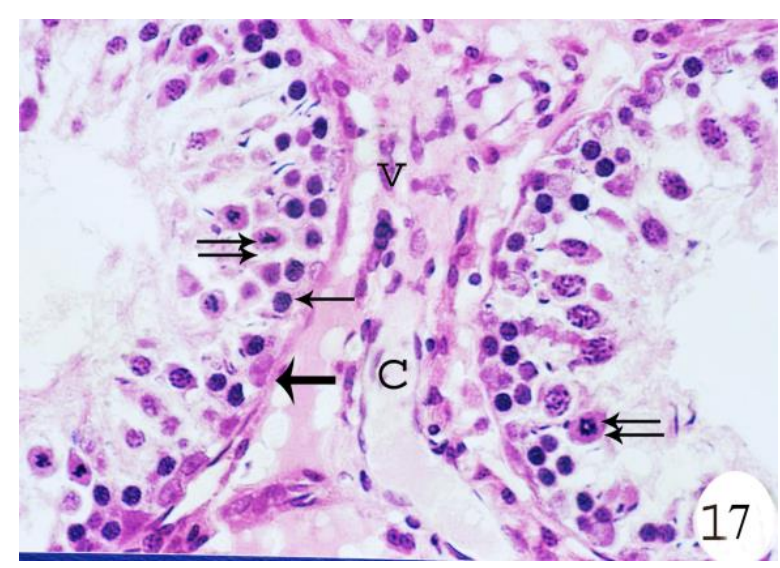

Fig. (17): A photomicrograph of a section in the testis of persistent hypothyroid adult rats (90 days old) treated with PTU for 90 days after birth showing seminiferous tubules with many basal Sertoli cells (thick arrow) some primary sepermatocytes (thin arrow) are widely separated and contain small dark nuclei. Other primary spermatocytes (double arrow) show different stages of division. Few sperms (arrow head) appear between the germ cells. Wide interstitial spaces containing many Leydig cells (C), vacuoles (V) and abundant interstitial fluid are also observed.

(H \& E X 400)

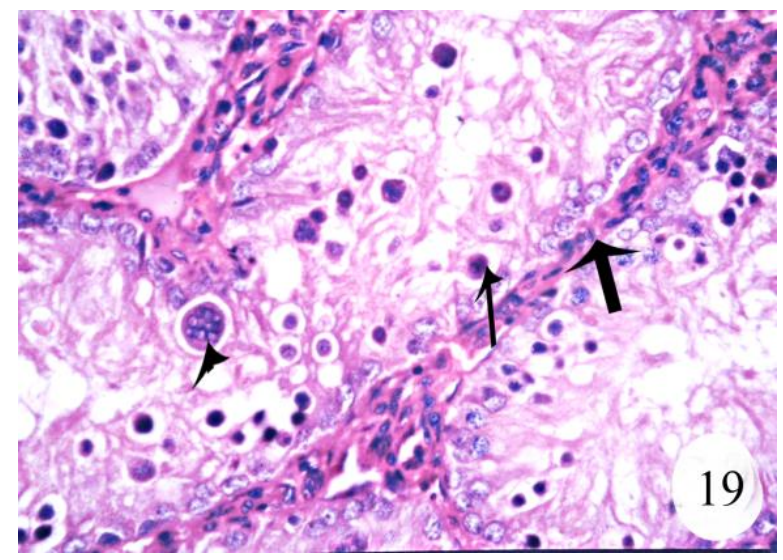

Fig. (19): A photomicrograph of a section in the testis of persistent hypothyroid adult rats (90 days old) treated with PTU for 90 days after birth showing seminiferous tubules lined by many Sertoli cells (thick arrow). Sloughed degenerated germ cells with dark and atrophied nuclei (thin arrow) and large multinucleated giant cells (arrow head) are seen in the lumen of the tubules.

(H \& E X 400)

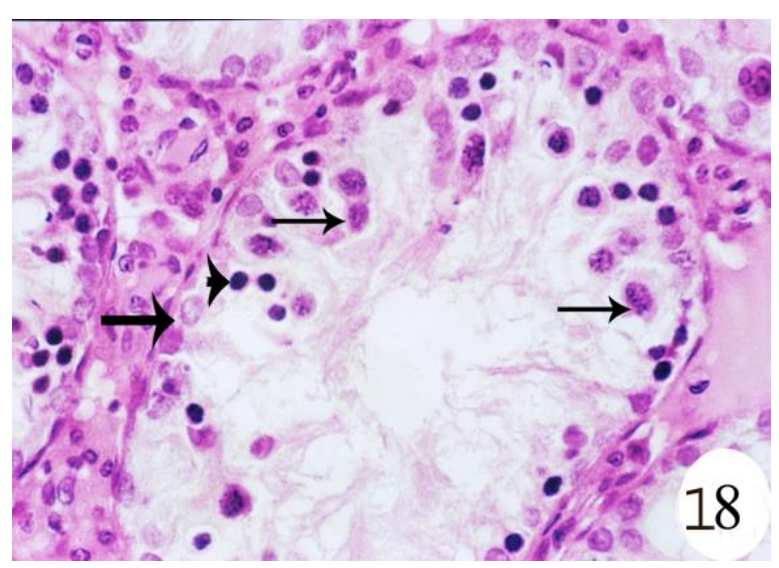

Fig. (18): A photomicrograph of a section in the testis of persistent hypothyroid adult rats (90 days old) treated with PTU for 90 days after birth showing seminiferous tubules lined by thin disorganized germinal epithelium. Many Sertoli cells (thick arrow) were seen close to the basement membrane. Few widely separated primary spermatocytes (thin arrow) are seen. Some of them have small dark nuclei (arrow head). Wide interstitial spaces with many Leydig cells, abundant fluid are also noticed. $\quad$ (H \& E X 400)

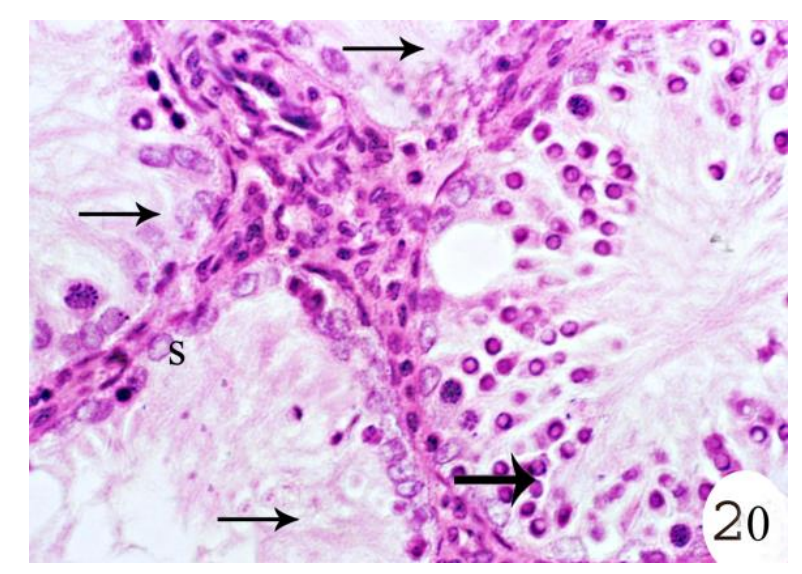

Fig. (20): A photomicrograph of a section in the testis of persistent hypothyroid adult rats (90 days old) treated with PTU for 90 days after birth showing seminiferous tubules (thin arrow) lined only by single layer of Sertoli cells (S) close to the basement membrane. Other ST (thick arrow) is lined by many Sertoli cells, primary spermatocytes and early spermatids, wide interstitial spaces with many cells are seen.

( $\mathrm{H} \& \mathrm{E} X$ 400) 


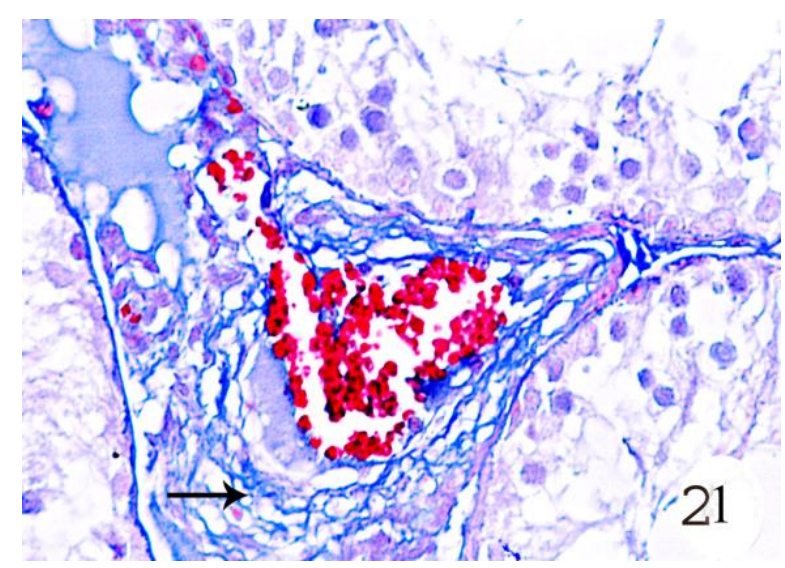

Fig. (21): A photomicrograph of a section in the testis of persistent hypothyroid adult rats (90 days old) treated with PTU for 90 days after birth showing seminiferous tubules separated by wide interstitial spaces containing congested blood vessels and many collagen fibers (arrow).

(Mallory's trichrome stain X 400)

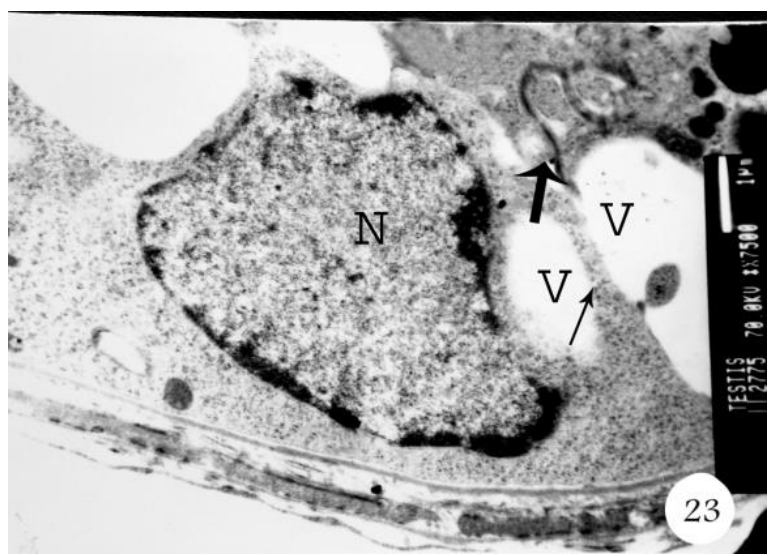

Fig. (23): A transmission electron micrograph of a section in the testis of persistent hypothyroid adult rats (90 days old) treated with PTU for 90 days after birth showing Sertoli cell containing nucleus (N) with condensed peripheral heterochromatin. Distorted tight junction (thick arrow) and vacuoles (v) between the processes of adjacent Sertoli cells (thin arrow) are also seen. (X 17000)

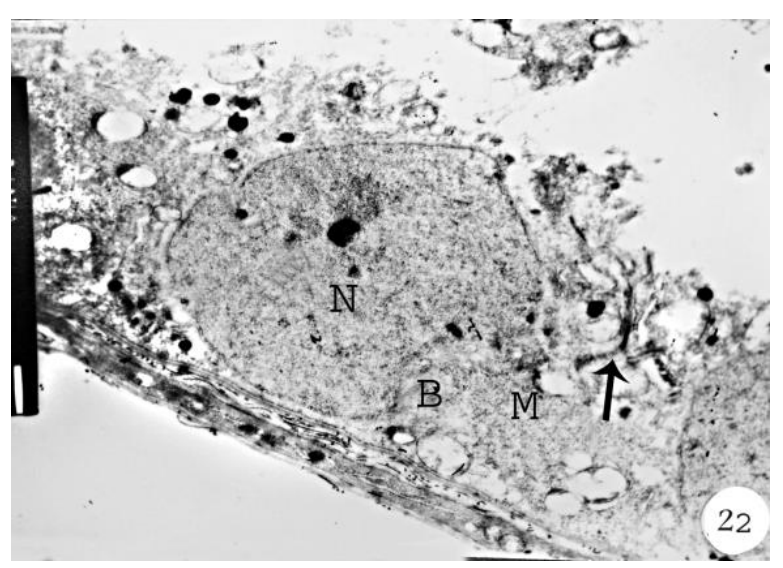

Fig. (22): A transmission electron micrograph of a section in the testis of persistent hypothyroid adult rats (90 days old) treated with PTU for 90 days after birth showing Sertoli cell resting on the basement membrane (B). It contains indented nucleus (N) with dispersed chromatin and distorted mitochondria (M). Disorganized tight junction (arrow) appears between Sertoli cells. (X 10000)

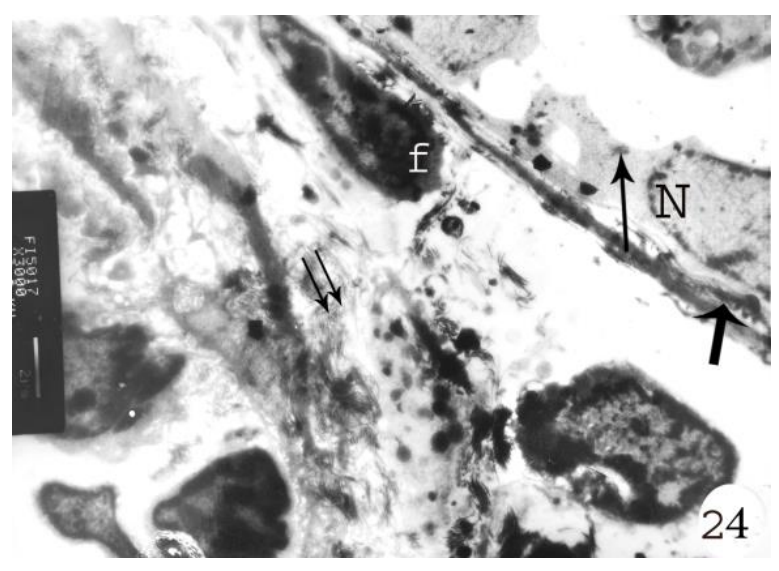

Fig. (24): A transmission electron micrograph of a section in the testis of persistent hypothyroid adult rats (90 days old) treated with PTU for 90 days after birth showing widely separated Sertoli cells (thick arrow) with free lateral processes (thin arrow) and nucleus (N) with peripheral heterochromatin condensation. The interstitial space contains many collagen fibers (double arrow) and fibroblasts (F). (X 6000) 
Table (1): The mean diameter of the seminiferous tubules in the testes of control, transient and persistent hypothyroid rats.

\begin{tabular}{|l|c|c|c|c|}
\hline & Control & $\begin{array}{c}\text { Transient } \\
\text { hypothyroidism }\end{array}$ & Control & $\begin{array}{c}\text { Persistent } \\
\text { hypothyroidism }\end{array}$ \\
\hline Mean diameter & $278.7 \pm 55.19$ & $309.41 \pm 27.68$ & $278.7 \pm 55.19$ & $158.36 \pm 38.12$ \\
\hline P-value & \multicolumn{2}{|c|}{0.000} & \multicolumn{2}{c|}{0.000} \\
\hline
\end{tabular}

* Statistically significant differences $\mathrm{P}<0.05$.

Table (2): The height of epithelium lining the seminiferous tubules in the testes of control, transient and persistent hypothyroid rats.

\begin{tabular}{|l|c|c|c|c|}
\hline & Control & $\begin{array}{c}\text { Transient } \\
\text { hypothyroidism }\end{array}$ & Control & $\begin{array}{c}\text { Persistent } \\
\text { hypothyroidism }\end{array}$ \\
\hline $\begin{array}{l}\text { Mean height of } \\
\text { epithelium }\end{array}$ & $70.39 \pm 9.19$ & $73.24 \pm 17.52$ & $70.39 \pm 9.19$ & $29.49 \pm 9.19$ \\
\hline P-value & \multicolumn{2}{|c|}{0.015} & \multicolumn{2}{c|}{0.000} \\
\hline
\end{tabular}

\section{DISCUSSION}

Thyroid hormone has an essential role in maintaining normal development, maturation and physiology of the testis(Sakai et al.,2004). In the previous studies, thyroid hormone deficiency has few serious effects on the adult testes except that occur during neonatal stage when the hypothyroidism influences the testicular growth and physiology adversely(Tahmaz et al.,2000).

In the present study, light microscope examination of the testes of adult transient hypothyroid rats, treated with PTU for 30 days after birth, revealed large seminiferous tubules with long diameters and narrow lumen. They were lined by many layers of germinal epithelium. These results were confirmed by morphometric analysis which indicated that the diameters of the seminiferous tubules in the testes of transient hypothyroid rats and the height of the epithelium lining them significantly increased as compared to those of control rats. The seminiferous tubules were lined by many Sertoli cells, spermatogonia, primary spermatocytes, early (round) spermatids and late (elongated) spermatids. Electron microscope examination of the testes of transient hypothyroid rats revealed spermatogonia and Sertoli cells resting on the basement membrane. Spermatogonia

appeared with mitochondria and nuclei containing peripheral clumps of heterochromatin while Sertoli cells were seen with indented nuclei containing dispersed chromatin. They had lateral processes which joined together around the spermatogonia. Primary spermatocytes contained mitochondria and nuclei with scattered clumps of heterochromatin. Early spermatid appeared with nuclei containing dispersed chromatin and peripheral mitochondria with electron dense membranes. Also, late spermatids were observed with electron dense nuclei and tails. These results were in accordance with those of Maran et a.l(1999).Maran et al(2001)and Sahoo et a.,l(2008). They reported that the transient neonatal hypothyroidism in rats results in increased testicular size in the adult which is associated with increased Sertoli and germ cell number and subsequently increased sperm production. Van Haaster et al.(1992) and Holsberger and Cooke(2005) suggested that neonatal hypothyroidism might increase adult Sertoli cell populations by extending Sertoli cell proliferation as a result of a delay in their differentiation leading to an increase in Sertoli and germ cell number. In hypothyroidism, delayed differentiation of Sertoli cells might be explained by two hypothesis. First, it might be secondary to lowered follicular stimulating hormone (FSH) and lutenizing hormone (LH) level found in the hypothyroidism presumably because of an effect of thyroxine on the pituitary gland(Simorangkir et al.,1997 and Kirby et al.,1977).Recently, it has been suggested that 
thyroid hormone regulates cellular proliferation and differentiation in the

testes directly by affecting on $\mathrm{T}_{3}$ receptors

which are present in the testes throughout postnatal development particularly in Sertoli cells which play a critical role in spermatogenesis (Bmzz and etal., 2002) A. In the rat testis, the thyroid receptors $\alpha 1$ gene is expressed(Canale et al.,2001).Furthermore, type 2 iodothyronine deiodinase, a thyroid hormone activating enzyme, is expressed in adult rat testis and its activity is induced by hypothyroidism(Wanger et al.,2003and Wajner et al.,2007).On the other hand, thyroid hormone affects in Sertoli cells function such as androgen metabolism, androgen binding protein mRNA levels(Panno et al.,1994) growth factors(Palmero et al.,1990)and aromatase activity(Ando et al.,2001).

Also, the present study revealed that the seminiferous tubules in the testis of transient hypothyroid rats were separated by interstitial spaces containing some cells. It has been suggested that thyroid hormone has a regulatory role on the cell populations of the testis interstitium. It is important for triggering the differentiation of highly proliferating mesenchymal cells, which are precursors of leydig cells, into adult leydig cells in neonatal rats(Hardy et al.,1996). So transient hypothyroidism prevent differentiation of mesenchymal cells and increase their number in the testis interstitium. Upon withdrawal of PTU treatment, the inhibition is removed and an increased number of leydig cell precursors are available to be differentiated. So, the number at adult leydig cells increase in the rat testis subjected to transient hypothyroidism (Mendis-Handagama et al.,1998). Also, Meisami et al.(1994)reported that the recovering testis (in transient hypothyroidism) might become sensitized to the thyroid hormones due to up regulation of the receptors resulting in enhanced testicular growth after normalization of the hormonal levels.

On the other hand, light microscope examination of the testes of persistent hypothyroid rats, treated with PTU for 90 days after birth, revealed small seminiferous tubules lined by thin widely separated and disorganized germinal epithelium. These results were confirmed by morphometric study which showed that the diameters of seminiferous tubules in the testis of persistent hypothyroid rats and the height of epithelium lining them significantly decreased as compared to those of control rats.

The most striking finding of the present study was the dense packing of many Sertoli cells forming a continuous layer along the basement membrane. They appeared with avoid pale nuclei and long cytoplasmic processes. Some disorganized processes of Sertoli cells were fused together forming large vacuoles between germ cells. Some seminiferous tubules were seen with few primary spermatocytes at different stages of division, early spermatids and few distorted late spermatids between the germ cells. Many sloughed degenerating germ cells with small pyknotic nuclei and pale cytoplasm, and large multinucleated giant cells were seen in the lumen of seminiferous tubules. These results were in accordance with those et of Hamouli-Said et al.(2007)and Sahoo et al. (2008)who reported that neonatal persistent hypothyroidism induced prolonged proliferation of Sertoli cells during postnatal development, delay in the appearance of spermatocytes and spermatids, subsequent apoptosis of the germ cells with appearance of sloughed multinucleated giant cells, reduction in the height of the epithelium lining the seminiphrous tubules and lower the testosterone level. Also, Simorangkir et al.(1997)suggested that the hypothyroidism induced histoarchitectural disturbance in the testis leading to accumulation of the germ cells and debris in the tubular lumen which might cause a disturbance in normal sperm release from Sertoli cells. These changes might be explained by several hypothesis. De Franca et al.,(De france etal., 1994) reported that neonatal persistent hypothyroidism might increase Sertoli cell population which is associated with delayed structural and functional maturation resulting in dramatic impairment of protein metabolism and level of specific biochemical markers. Biochemical immaturity of the Sertoli cells at hypothyroid rats leading to failure of Sertoli cells to produce paracrine agents essential in maintenance of spermatogenesis and decrease in germ cell numbers. On the other hand, thyroid hormone is considered as a major of oxygen consumption and mitochondrial energy metabolism. During oxidative metabolism in 
mitochondria, highly reactive oxygen species (ROS) such as hydroxyl radical, superoxide anion, and hydrogen peroxide are naturally generated in small amount. If not disposed of quickly, they can attack biomolecules and cause impairment of cellular function. There are antioxidant defense enzymes and molecules that neutralize ROS generation in order to keep the cells in normoxidant condition(Chattopadhyay et al.,2007) Alteration of thyroid hormone level is known to modulate the function of several tissues by modulating their antioxidant defense system(Sahoo and Chany,2007).Transient hypothyroidism leads to metabolic depression which serves as a protective factor to prevent lipid peroxidation. However, in persistent hypothyroidism, the induction of oxidative stress is reflected by increased lipid peroxidation of the cell membrane of different spermatogemic cells(Mogulkoc et al.,2005) and reduced biosynthesis of antioxidative enzymes(Sahoo et al.,2006).

In the present study electron microscope exmaination of testes of persistent hypothyroid rats revealed sertoli cells with distorted mitochondria and nuclei containing peripheral clumps of heterochromatin. Sertoli cells were surrounded by wide spaces due to loss of germ cells. They appeared widely separated with free processes due to loss of tight junction between them. These results were in agreement with those of Stock and $\operatorname{Sies}(2000)$ who suggested that the thyroid hormone may be necessary for the formation of tight junctions between Sertoli cells. In rats, tight junction in Sertoli cells are formed at the base of seminiferous tubules at approximately 14 days of age which result in the formation of blood testis barrier(Moiori et al.,1998).Testicular tight junction are composed of several transmembrane proteins, including occluding, several; claudins and connexin 43. It has been reported that connexin 43 and occluding can co-localize within the intercellular junction complex such as zona occludens-1(Giepmans and Moolenaar, 1998) .Thyroid hormone act directly on connexin 43 to regulate its expression (Bates etal.,1999). Also, it is necessary for the interaction between connexin 43 occluding and zona occludens- 1 . Hypothyroidism delays the formation of tight junction between Sertoli cells as a result of alterations in the localization of occluding between Sertoli cells(St-Pierre $\boldsymbol{e t}$ al.,2003).

Furthermore, in the present study, light and electron microscope examination of the testes of persistent hypothyroidism rats revealed wide interstitial spaces containing many cells, excessive collagen fibers, congested blood vessels and abundant interstitial fluid. These findings were in agreement with those of Teerds et al.(1998)who suggested that the persistent hypothyroidism delays the differentiation of mesenchymal precursors cells into adult leydig cells leading to increase the number of mesenchymal cells and decrease the adult leydig cell numbers in the interstitial spaces of the testes. Moreover, MendisHandagama et al (1998) reported reduction in leydig cells, along with increase in the connective cells in the testis interstitium of hyperthyroid rats. Also, Hardy et al.(1996) suggested that the hypothyroidism induced disruption of spermatogenic and steroidogenic processes leading to significant decrease in serum testosterone level.

On the other hand, the present study revealed the presence of abundant fluid in the interstitial spaces between seminiferous tubules. This finding can be explained by the fact that the Steroli cells may regulate the testicular interstitial fluid volume which is index of alteration in interstitial hormone level. So, prolonged proliferation of Sertoli cells as a result of hypothyroidism lead to increase testicular interstitial fluid(Sharpe et al.,1991). In conclusion, the present study revealed that the neonatal transient hypothyroidism enhanced the growth of the testes that they contain large seminiferous tubules with many germ cells. While, persistent hypothyroidism induced testicular atrophy with loss and degeneration of germ cells. So, estimation of thyroid hormone level is recommended in all neonates immediately after birth for early diagnosis and treatment of thyroid hormone deficiency to prevent serious adverse effect of hypothyroidism on the testis.

\section{REFERENCES}

1- Ando S, Sirianni R, Forastieri P, Casaburi I, Lanzino M, Rago V, Giordano F(2001): Aromatase expression in prepubertal sertoli cells: effect of thyroid hormone. Mol.Cell .Endocrinol; 10: 178 (12): 11-21. 
2- Bancroft JD and Gamble M(2002): Theory and Practice of Histological Techniques $5^{\text {th }}$ ed, Churchill Livingstone London, New York, Philadelphia, Toronto.

3- Bates JM, St Germain DL and Galton VA(1999): Expression profiles of the three iodothyronine deiodinase D1, D2, D3 in developing rat. Endocrinology ,440: 844-851.

4- Biswas NM, Ghosh PK, Biswas R,and Ghosh D(1994): Effect of thyroidectomy and thyroxine and $\alpha_{20}$-globulin replacement therapy on testicular steroidogenic and gametogenic activities in rats. J .Endocrinol; 140: 343-347.

5- Buzzard JJ, Morrison JR, O'Pryan MK, Song Q and Wreford NG(2002): Developmental expression of thyroid hormone receptors in the rat testis. Biol .Reprod; 62: 664-669.

6- Canale D, Agostini M, Giorgili G and Gaglieresi C(2001): Thyroid hormone receptors in neonatal, prepubertal and adult rat testis. J. Androl; 22: 284288.

7- Chastain MA, Russo GG, Boh EE, Chastain JB, Fatabella A and Millikan LE (1999):Propylthiouracil hypersensitivity: report of two patients with vasculitis and review of the literature. J. Am.Acad .Dermatol ; 41: 757-764.

8- Chattopadhyay S, Sahoo DK, Subudhi U and Chainy GBN(2007): Differential expression profiles on antioxidant enzymes and glutathione redox status in hyperthyroid rats. A temporal analgsis. Comp. Biochem .Physiol.,146: 380-391.

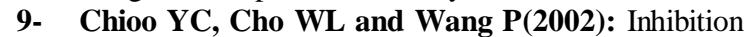
of testosterone production by propylthiouracil in rat leydig cells. Biol.Reprod; 67: 416-422.

10- Choksi NY, Jahnke GD and Shelby M(2003): Role of thyroid hormones in human and laboratory animals reproductive health. Birth Defects Research Part B. Developmental and Reproductive Toxicology ,68: 479-491.

11- De Felice Mand Di lauro R(2004): Thyroid development and its disorders; genetics and molecular mechanisms. Endocrine. Reviews,25: $722-746$.

12- De Franca LR, Hess RA, Cooke PS and Russel LD(1994): neonatal hypothyroidism causes delayed Sertoli cell maturation in rats treated with propylthiouracil evidence that the Sertoli cell controls testis growth. Anat .Rec; 242: 57-69.

13- Deidiker $R$ and de Mello DE(1996): Propylthiouracil induced fulminant hepatitis case report and review of literature. Pediatr. Pathol .Lab. Med., 16: 845-852.

14- Giepmans BNG and Moolenaar WH(1998): The gap junction protein connexin 43 interacts with second PDZ domain of the zona occludens-1 protein. Curr .Biol; 8: 931-934.

15- Glauert AM and Lewis PR(1998): Biological Specimen Preparation for Transmission Electron Microscopy. Volume 17, Portland Press, London.

16- Hamouli-Said Z, Tahari E, Hamoudi F and HadjBekkouche D (2007): Comparative study of the pre and post natal administration of a thyroid drug on testicular activity in adult rat. Folia Histochemical Et CytoBiologica ,45 (1): 51-57.

17- Hardy MP, Sharma RS, Arambepola NK, Sottas CM and Russel LD(1996): Increased proliferation of leydig cells induced by neonatal hypothyroidism in the rats. J .Androl; 17: 231-238.

18- Holsberger DR and Cooke PS(2005): Understanding the role of thyroid hormone is sertoli cell development: a mechanistic hypothesis. Cell Tissue Res; 322: 133-140.

19- Jannini EA, Ulisse Sand D'Armento M(1995): Thyroid hormone and male gonadal function. Rev ., 16: 443-459

20- Kirby JD, Arambepola N, Porkka-Heiskanen T and Kirby YK (1997).: Neonatal hypothyroidism permanently alters follicle-stimulating hormone and luteinizing hormone production in the male rate. Endocrinology , 138 (7): 2713-2721.

21- Loveland K, Schlatt S, Sasaki T, Chu ML, Tim p and Dziadek M(1998):Developmental changes in the basement membrane of the normal and hypothyroid postnatal rat testis. Segmental Localization of Fubulin-2 and Fibronectin. Biol. Reprod; 58: 1123-1130.

22- Maran RR, Sivakumar R, Aruinakaran J, Ravisankar B, Ravichandran K, Sidharhan V, Jeyaraj DA and Aruldhas MM(1999): Duration dependant effect of transient neonatal hypothyroidism on Sertoli and germ cell number and plasma and testicular interstitial fluid androgen binding protein concentration. Endocrinol. Res; 25: 323-340.

23- Maran RRM, Ravichandran K, Arunakaran J and Aruldhas M(2001): Impact of neonatal hypothyroidism on leydig cell number, plasma and testicular interstitial fluid sex steroids concentration. Endocrine Research, 27 (1,2): 119-141.

24- Meisami E, Najafi A and Timiras PS(1994): Enhancement of seminiferous tubular growth and spermatogenesis in testis of rats recovering from early hypothyroidism. A quantitative study. Cell Tissue Res; 275: 503-511.

25- Mendis-Handagama SM, Ariayaratne HB, Teunissen van manen KR and Haupt RL(1998): Differentiation of adult leydig cells in the neonatal rat testis is arrested by hypothyroidism. Biol. Reprod; 59 (2): 351-357.

26- Mogulkoc R, Baltaci AK, Oztekin E, Ozturk A and Sivrikaya $\mathbf{A}(\mathbf{2 0 0 5})$ : Short term thyroxine administration leads to lipid peroxidation in renal and testicular tissues of rats with hypothyroidism. Acta Biol. Hung; 56: 225-232.

27- Moiori S, Saitou M, Fujimoto K, Sakakibara A, Furuse M, Yoshida $O$ and Tsukita $\mathrm{SH}(1998)$ : Occludin is concentrated at tight junction of mouse/rat but not human/guinea pig sertoli cells in testes. Am. J. Physiol; 274: 1708-1717.

28- Momotani N, Yamashita R, Makino F, Noh JY, Ishikawa $\mathbf{N}$ and Ito $\mathbf{K}(\mathbf{2 0 0 2})$ : Thyroid function in wholly breast-feeding infants whose mothers take high doses of propylthiouracil. Clin .Endocrinol; 53: 177-181.

29- Morchart B, Brownlie BEW, McKay, Harnt D, Horton PWand Alexander WD(1977): The placental transfer of propylthiouracil, methimazole and carbimazole. J .Clin .Endocrinol .Metab; 45: 1187-1193.

30- Morreale de Escobar G, Pastor RE, Obregon MJ, Escobar D and Rey F (1985):Effect of maternal hypothyroidism on the weight and thyroid hormones 
content of rat embryonic tissues before and after onset of fetal thyroid function. Endocrinology, 117: 1890-1900.

31- Palmero S, Prati M, Barreca A, Miinuto F, Giordano $G$ and Fugassa E(1990): Thyroid hormone stimulates the production of insulin-like growth factor 1 (IGF-1) by immature rat Sertoli cells. Mol. Cell Endocrinol; 68: 61-65.

32- Panno ML, Beralkdi E, Pezzi V, Salerno $M$ and DeLuca G(1994): Influence of thyroid hormone on androgen metabooism in prepupertal rat sertoli cells. J. Endocrinol; 140: 349-355.

33- Rao JN, Liang JY, Chakraborti Pand Feng P(2003): Effect of thyroid hormone on the development and gene expression of hormone receptors in rat testis in vivo. J Endocrinol. Invest; 26: 435-443.

34- Sahoo DK and Chainy GBN(2007): Tissue specific response of antioxidant defence systems of rat to experimentally-induced hyperthyro-idism. Natl .Acad. Sci .Lett; 30: 247-250.

35- Sahoo DK, Roy A, Bhanja $S$ and Chainy GBN(2008): Hypothyroidism impairs antioxidant defence system and testicular physiology during development and maturation. General and Comparative Endocrinology ,156: 63-70.

36- Sakai Y, Yamashina $S$ and Faruedate $S(2004)$ : Developmental delay and unstable state of the testes in the rdw rat with congenital hypothyroidism. Dev. Growth Differ., 46 (4): 327-334

37- Sahoo DR, Roy A and Chainy GBN(2006): PTUinduced neonatal hypothyroidism modulates antioxidant status and population of rat testicular germ cells. Natl. Acad. Lett; 29: 133-135.

38- Sharpe RM, Bartlett JM and Allenby G(1991): Evidence for the control of testicular interstitial fluid volume in the rat by specific germ cells types. J .Endocrinol; 128: 359-367.

39- Sharpe RM, McKmnell $C$, Kivlin $C$ and Fisher JS(2003): Proliferation and functional maturation of sertoli cells and their relevance to disorders of testis function in adulthood. Reproduction ,125: 769- 784

40- Simorangkir DR, DeKretser DM and Wreford NG (1997): Increased numbers of Sertoli and germ cells in adult rat testis induced by synergic action of transient neonatal hypothyroidism and neonatal hemicastration. J .Reprod .Fertil; 104: 207-213.

41- Simorangkir DR, Wreford NG and De Kretser DM(1997): Impaired germ cell development in the testis of immature rats with neonatal hypothyroidism. J .Androl; 18: 186-193.

42- Stock A and Sies H(2000): Thyroid hormone receptors bind to an element in the connexin 43 promotor. J .Biol .Chem; 381: 973-979.

43- St-Pierre N, Dufresne J, Rooney AA and Cyr DG(2003): Neonatal hypothyroidism alters the localization of gap junctional protein connexin 43 in the testis and messenger RNA level in the epididymis of the rat. Biol. Reprod; 68 (4): 12321240.

44- Tahmaz L, Gokalp A, Kibar Y, Kocak I, Yalcin Q and Ozercan Y(2000): Effect of hypothyroidism on the testes in mature rats and treatment with levothyroxine and zinc. Andrologia , 32: 85-89.

45- Teerds KJ, Rooij DG, Jong FH and Haaster LH: Development of the adult-type leydig cell population in the rat is affected by neonatal thyroid hormone levels. Biol .Repord; 59 (2): 344-350.

46- Ten PM(2001): Physiological and molecular basis of thyroid hormone action. Physiol.Rev., 81: 10971142.

47- Van Haaster LH, DoJong FH, Dockter R and De Rooij D G(1992): The effect of hypothyroidism on Sertoli cell proliferation and differentiation and hormone level during testicular development in rats. Endocrinology, 131: 1574-1576.

48- Wagner MS, Morimoto R, Dora JM, Benneman A, Pavan R and Maia AL(2003): Hypothyroidism induces type 2 iodothyronine deiodinase expression in mouse heart and testis. J .Mol. Endocrinol; 31 (3): 541-50. 


\section{تأثير النقص المؤقت والدائم لإفراز الغدة الدرقية المحدث في الجرذان البيضاء حديثة الولادة على خصية الجرذان البالغة}

\section{ليلى مصطفى الثال}

قسم الهستولوجي - كلية الطب - جامعة الزقازيق

أجرى هذا البحث على ثلاثين من ذكور الفئران البيضاء حديثة الولادة والتي تبلغ من العمر يوما واحداً وذلك لمقارنة تأثير

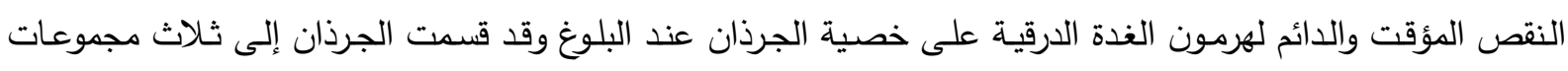
متساوية وهى المجموعة الضابطة والمجموعة التجريبية الأولى التى أحدث فيها نقص مؤقت في هرمون الغدة الدرقية في الجرذان حديثة الولادة بإعطاء الأم 0.05\% 6-بروبايل -2-ثايويوراسيل المذاب في ماء الثرب عن طريق الفم لمدة ثلاثين

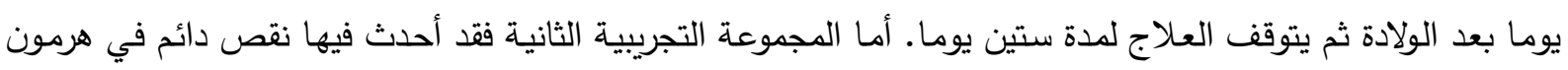

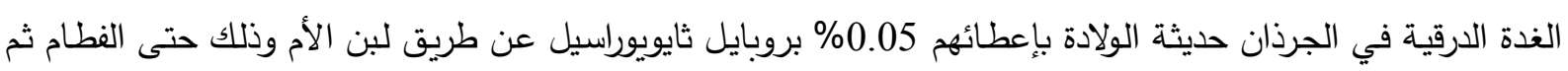

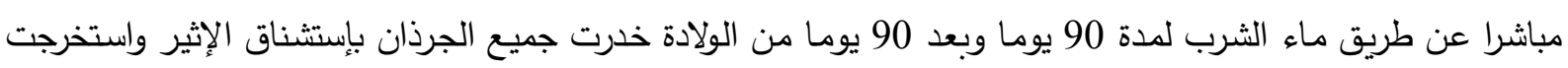

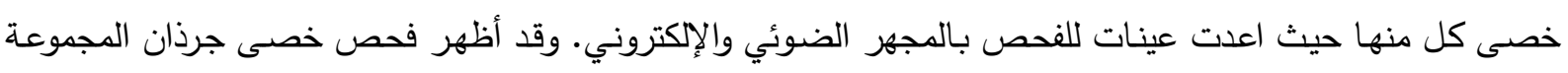

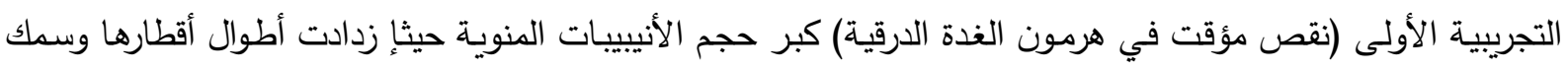
النسيج الطلائي الجرثومي المبطن لها مقارناً بالمجموعة الضابطة وقد بطنت هذه الأنيبيات بغشاء طلائي مكون من العديد

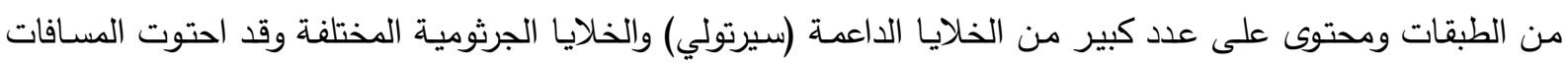

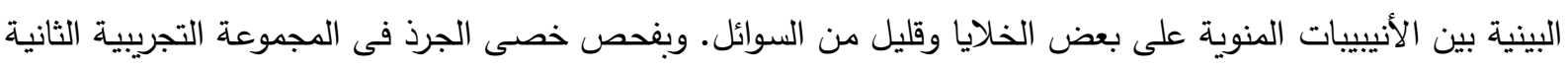

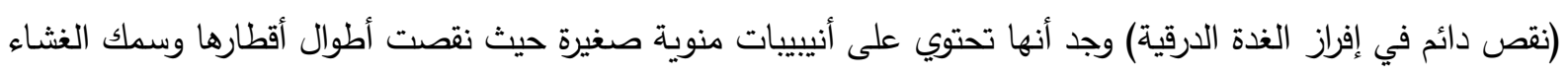

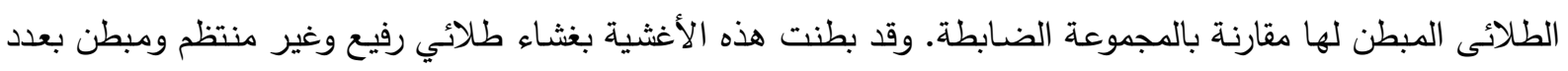

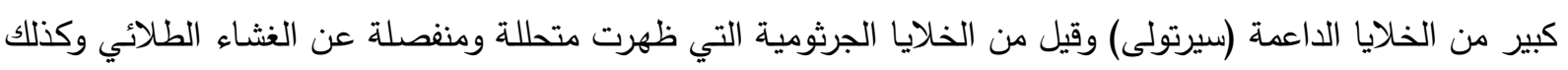
ظهرت خلايا عملاقة ذات أنوية متعددة داخل تجاويف الأنابيب المنوية. وقد احتوت المسافات البينية بين الأنابيب المئية المنوية

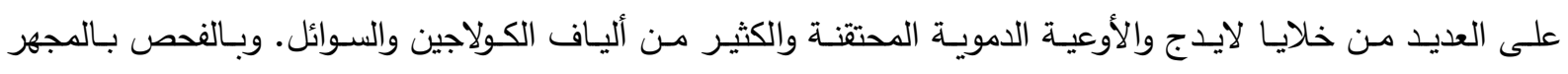

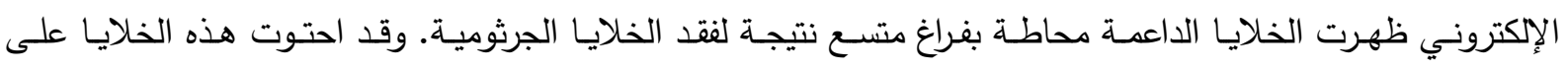

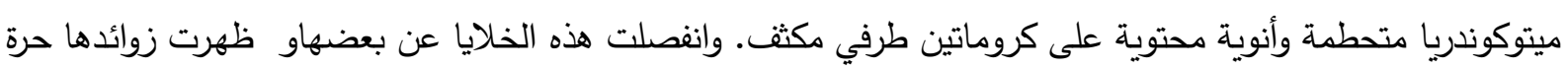
نتيجة لفقد الإرتباط بينها.

وهكذا نستتتج من هذه الدراسة أن النقص المؤقت لإقراز الغدة الدرقية فى صغار الجرذان يؤدي إلى زيادة نمو

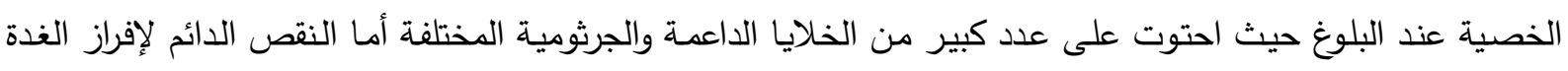

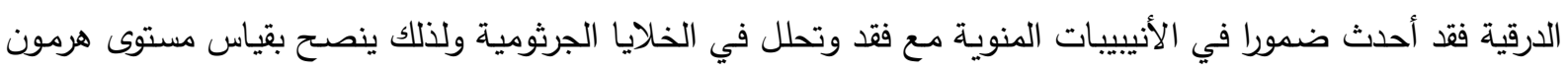

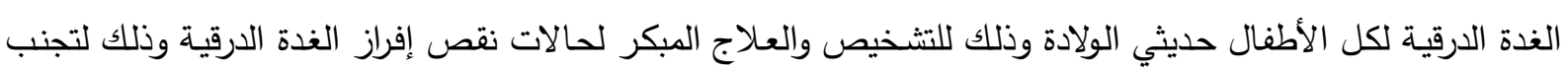
الآثار الجانبية الضارة لنقص هذا الهرمون على الخصية. 